\title{
META ANALISIS EFEKTIVITAS MULTIMEDIA INTERAKTIF UNTUK MENINGKATKAN COGNITIVE SKILL PESERTA DIDIK DALAM BELAJAR KIMIA
}

\section{META ANALYSIS STUDY OF THE EFFECTIVENESS OF INTERACTIVE MULTIMEDIA TO IMPROVE STUDENT'S COGNITIVE SKILL IN LEARNING CHEMISTRY}

\author{
Siti Arofah dan *Rinaningsih \\ Jurusan Kimia FMIPA Universitas Negeri Surabaya \\ e-mail: $\underline{\text { rinaningsih@ } \text { unesa.ac.id }}$
}

\begin{abstract}
Abstrak
Tujuan penelitian adalah untuk mengetahui efektivitas penggunaan multimedia interaktif terhadap peningkatan kemampuan kognitif peserta didik dalam pembelajaran kimia dengan mensintesis beberapa literature terkait. Multimedia interaktif diartikan sebagai kesatuan dari suara, video, data, audio, animasi, grafik, dan teks yang setiap bagian dari beberapa gabungan tersebut dapat dipaparkan dengan perantara media elektronik seperti komputer, laptop, atau android. Metode yang digunakan yaitu metode meta analisis dengan cara membandingkan informasi melalui beberapa studi literatur penelitian yang sejenis. Berdasarkan hasil analisis beberapa literatur yang telah dikumpulkan, penggunaan multimedia interaktif dalam pembelajaran dapat meningkatkan kemampuan kognitif peserta didik dalam pembelajaran kimia. Perbandingan hasil analisis peningkatan kemampuan kognitif pada peserta didik dapat diamati dari persentase data pretest dan posttest efektivitas penggunaan media pembelajaran multimedia interaktif yang kemudian dilakukan uji statistik paired sample. Berdasarkan hasil uji analisis diketahui rata-rata persentase pretest dan posttest efektivitas penggunaan media pembelajaran multimedia interaktif dalam pembelajaran kimia yaitu sebesar 48,67\% dan 79,60\%. Analisis data diolah menggunakan uji statistik paired sample dan effect size. Rata-rata peningkatan antara pretest dan posttest yaitu sebesar 30,93\% dan diperoleh nilai effect size sebesar 1,47689. Hasil penelitian ini menunjukkan bahwa penggunaan media pembelajaran multimedia interaktif efektif dapat meningkatkan kemampuan kognitif peserta didik dalam pembelajaran kimia.
\end{abstract}

Kata kunci: Kognitif skills, pembelajaran kimia. multimedia interaktif

\begin{abstract}
The objective of this research is to determine the effectiveness of interactive multimedia on improving students' cognitive skill in chemistry learning through synthesize some literature. Interactive multimedia is defined as the unity of sound, video, data, audio, animation, graphics, and text, each part of some of these combinations can be presented with electronic media intermediaries such as computers, laptops, or androids. The method used is the meta-analysis method by comparing information through several studies of uniform research literature. Based on the results of the analysis of some of the literature that has been collected, the use of interactive multimedia in learning can improve students' cognitive skill in chemistry learning. The comparison of the results of the analysis of the increase in cognitive skill in students can be observed from the percentage of pretest and posttest data on the effectiveness of using interactive multimedia learning media which is then carried out by paired sample statistical tests. Based on the results of the analysis test, it is known that the average percentage of the pretest and posttest effectiveness of using interactive multimedia learning media in chemistry learning is $48.67 \%$ and $79.60 \%$. Data analysis was processed using paired sample statistical tests and the effect size. The average increase between the pretest and posttest is $30.93 \%$ and the effect size value is 1.47689. The results of this study indicate that the use of interactive multimedia learning media can effectively improve the cognitive skill of students in learning chemistry.
\end{abstract}

Key words: Cognitive, chemical. interactive multimedia 


\section{PENDAHULUAN}

Pada era ini, bidang teknologi, informasi, dan komunikasi sedang dalam keadaan yang berkembang pesat. Hal itu tentunya berperan penting juga dalam bidang pendidikan terutamanya dalam pembelajaran. Pemanfaatan TIK secara kreatif pada aspek pendidikan dapat membuat perbedaan yang besar terhadap proses pembelajaran yaitu dari cara guru mengajar, cara belajar, dan penggunaan TIK dapat membantu peserta didik memperoleh keterampilan abad 21 [1]; [2].

Perkembangan teknologi ini dapat dimanfaatkan guru untuk menunjang proses pembelajaran termasuk pada proses pembelajaran materi kimia. Dalam arti, pembelajaran kimia tidak lagi hanya disampaikan dengan metode ceramah dimana peserta didik hanya menjadi pembelajar yang pasif, sedangkan guru pendidik yang aktif, namun guru harus dapat menyediakan fasilitas untuk belajar secara mandiri [3]; [4]; [5]; [6]; [7].

Ilmu Kimia dalam pengkajiannya mengharuskan peserta didik dapat memahami konsep yang abstrak, berupa angka atau hitungan dan juga praktikum, tetapi ilmu kimia juga sering dirasa susah untuk dipahami oleh peserta didik sehingga berpengaruh pada motivasi belajarnya yang menurun [2]; [8]. Hal itu yang menyebabkan materi pembelajaran kimia tidak menarik karena proses pembelajaran hanya bertumpu pada guru dan sulit dipahami dan ditangkap konsep materinya oleh peserta didik.

Guru harus mewujudkan materi ilmu kimia yang dirasa susah oleh perserta didik menjadi mudah untuk dipelajari dan dipahami. Maka dari itu kajian ilmu kimia harus diajarkan pada peserta didik dalam tiga tingkatan yaitu representasi, makroskopis, mikroskopis dan simbolis [9]. Agar penyajian materi kimia menjadi lebih menarik, guru harus dapat membentuk KBM (Kegiatan Belajar-Mengajar) yang menarik juga misalnya menggunakan model yang dipadukan dengan penggunaan media pembelajaran yang interaktif [10]. Di era modern dengan kecanggihan teknologi juga masa pandemi seperti ini guru juga dituntut untuk menggunakan pendekatan TPACK (Technological Pedagogical Content Knowledge) agar proses pembelajaran jarak jauh juga sesuai dengan karakteristik peserta didik. Guru juga harus memiliki keterampilan dalam mengajar, menggunakan metode, mengatur tahapan belajar, memanfaatkan media pembelajaran dan dapat mengendalikan waktu [1].

Oleh karena itu, guru harus dapat membuat media dalam kegiatan pembelajaran yang unik, interaktif, efektif, juga menyenangkan agar kegiatan pembelajaran kimia yang abstrak dan sulit dipahami menjadi mudah untuk dipelajari dan di pahami sehingga mampu meningkatkan hasil belajar peserta didik [11]; [12]; [13]; [14]. Dalam mewujudkan hal tersebut diperlukan sebuah strategi dalam bentuk metode pembelajaran, model pembelajaran, ataupun media pembelajaran yang tepat dan efektif dalam proses kegiatan belajarmengajar pada materi kimia.

Terdapat permasalahan utama lainnya yang masih ditemui yaitu rendahnya belajar kognitif pada peserta didik. Berdasarkan fakta diperoleh nilai kognitif peserta didik untuk mata pelajaran kimia masih di bawah nilai KKM [10]. Dan juga berdasarkan observasi yang telah dilakukan, diidentifikasi bahwa siswa kelas XI SMA Kesatrian Semarang kurang aktif dalam kegiatan KBM materi kimia yang berpengaruh pada hasil belajar kimia peserta didik [15]. Kesulitan memahami konsep mengenai aspekaspek dalam materi kimia akan berdampak negatif pada peserta didik mengenai konsep-konsep kimia karena sifat materi kimia yang abstrak.

Berhubungan dengan permasalahan tersebut, butuh dilakukan perbaikan dan juga inovasi dalam kegiatan proses belajar-mengajar pada pembelajaran kimia, yaitu dengan mengembangkan dan menerapkan media pembelajaran multimedia interaktif yang mampu menyajikan konsep ilmu kimia yang abstrak dan sulit digambarkan atau disajikan secara langsung di laboratorium kimia [16]. Gambar, teks, animasi atau suara yang menggambarkan informasi dari teks yang dapat mendukung ingatan dan pemahaman pada pengolahan kognitif peserta didik. Lebih utamanya yaitu pada pengaruh dari mengingat yang lebih baik dapat dijelaskan dengan teori kognitif dalam pembelajaran multimedia (Cognitive theory of multimedia learning) [17]. 
Multimedia merupakan sebuah media pembelajaran yang dapat membantu dalam KBM untuk meningkatkan pemahaman konsep dan kemampuan kognitif peserta didik dengan visual, audio, suara, dan animasi dengan bantuan teknologi elektronik [2]; [10]; [18]; [19]; [20]; [21]; [22]; [23]; [24]; [25]; [26]; [27]; [28]; [29]; [30]; [31]; [32]; [33]; [34]; [35]; [36]; [37]; [38]; [39]; [40]; [41]; [42]; [43]; [44]; [45]; [46]; [47]; [48]; [49].

Pembelajaran yang memanfaatkan multimedia interaktif mengharuskan peserta didik fokus terhadap isi topik yang disajikan. Karena multimedia interaktif bermuatan bagian-bagian media yang lengkap yaitu meliputi suara, video, grafis, teks, dan animasi yang membuat peserta didik dapat interaktif untuk berinteraksi melalui fitur-fitur yang ada di dalam media tersebut [50]; [51].

Secara umum multimedia interaktif diartikan sebagai kesatuan dari suara, video, data, audio, animasi, grafik, dan teks yang setiap bagian dari beberapa gabungan tersebut dapat dipaparkan dengan perantara media elektronik seperti komputer [52]. Multimedia interaktif merupakan sebuah multimedia yang dapat dikontrol oleh pengguna, sehingga dapat memilih apa yang diinginkan untuk proses berikutnya [53]. Media pembelajaran interaktif merupakan media yang digunakan dalam pembelajaran dan dapat mengolah respon juga pesan dari peserta didik, atau media pembelajaran yang mampu berkorelasi dengan peserta didik sehingga media tersebut memiliki sifat resiprokal, misalnya komputer, laptop, android, dan lain-lain [15].

Artikel ini bertujuan untuk mengidentifikasi efektivitas penggunaan multimedia interaktif sebagai media pembelajaran kimia untuk meningkatkan kemampuan kognitif peserta didik. Hasil tinjauan dari beberapa literatur disusun penulis sebagai artikel review dengan membandingkan hasil siklus akhir penggunaan multimedia interaktif terhadap kemampuan kognitif peserta didik. Berdasarkan penjelasan diatas, maka pertanyaan penelitian yang akan dianalisis pada artikel review ini yaitu "Bagaimana efektivitas penggunaan multimedia interaktif untuk meningkatkan kemampuan kognitif peserta didik dalam pembelajaran kimia?".

\section{METODE}

Penelitian artikel review ini merupakan tinjauan sistematis (Systematic Review) dengan menggunakan metode meta analisis. Meta analisis adalah sebuah analisis kuantitatif yang membutuhkan beberapa jumlah data untuk disertakan pada uji statistik dan diterapakan pada informasi-informasi dari sampel yang besar yaitu artikel-artikel yang telah dikumpulkan yang bertujuan dalam menyempurnakan tujuan lainnya [54]; [55]; [56]; [57]; [58]; [59]; [60].

Data yang diperoleh dari hasil penelusuran kemudian dilakukan analisis melalui uji statistik paired sample dengan membandingkan data pretest dan posttest dari artikel yang telah diperoleh. Jenis metode meta analisis yang digunakan dalam penelitian yaitu Study Effect Size yang bertujuan untuk mengetahui besar keefektifan dari penggunaan multimedia interaktif untuk meningkatkan kemampuan kognitif dalam pembelajaran kimia. Perhitungan Effect Size menggunakan rumus:

Effect Size $=\frac{\text { Posttest average score-Pretest average score }}{\text { standart deviation }}$

Dengan interpretasi Effect Size untuk single group pada Tabel 1.

Tabel 1. Interpretasi Effect Size

\begin{tabular}{cc}
\hline Size & Interpretation \\
\hline $0-0,020$ & Weak \\
$0,21-0,50$ & Modest \\
$0,51-1,00$ & Moderate \\
$>1,00$ & Strong \\
\hline
\end{tabular}

[61].

Hasil pemilihan artikel penelitian didapatkan 16 penelitian yang relevan. Penyajian data menggunakan persentase pretest dan posttest untuk mengukur kemampuan kognitif peserta didik. 16 artikel yang telah dianalisis datanya pada penelitian ini sebagai perbandingan yaitu penelitian oleh Lenni Khotimah Harahap dan Anggi Desviana Siregar (2020) [2]; Khaidir (2020) [10]; Agung Tri Prasetyo, Sigit Priatmoko, dan Miftakhudin (2008) [33]; Zeynep Tatli dan Alipasa Ayas (2013) [34]; Ida Hariyanti, Haryono, dan JS. 
Sukardjo (2013) [35]; Toto Gusbandono, JS. Sikardjo, Suryadi Budi Utomo (2013) [36]; Riana Lilis Widyawati, Suryadi Budi Utomo, dan Sulistyo Saputro (2016) [37]; Muthmainna Salam, Muharram, dan Army Aulia (2016) [38]; Gustina, St. Hayatun Nur Abu, dan Eka Fitriana Hamsyah (2016) [39]; Sri Wahyuni, Amna Emda, dan Hayatuz Zakiyah (2018) [40]; Dian Puspita Eka Putri,dan Ali Muhtadi (2018) [41]; Ratna Kumala Dewi, Sri Haryani, dan Sri Wardani (2018) [42]; Sarah L. Cresswell, Wendy A. Loughlin, Mark J. Coster, dan David M. Green (2019) [43]; Dian Puspita Eka Putri (2019) [44]; Sihaqqul Firdaus A. H. dan Rusly Hidayah (2019) [45]; dan Isna Rezkia Lukman dan Andi Maria Ulfa (2020) [46]

Penulusuran artikel penelitian yang berkaitan dengan topik penelitian dilakukan dengan menggunakan key word : cognitive, metaanalysis, learning chemistry, interactive multimedia, systematic review, dan kemampuan kognitif,

\section{HASIL DAN PEMBAHASAN}

Berdasarkan hasil penelusuran populasi dalam penelitian yaitu semua artikel yang diterbitkan oleh Researchgate, Science direct, google scholar, Elsevier, jurnal nasional, dan jurnal internasional lainnya yang memiliki topik relevan yaitu efektivitas multimedia interaktif untuk meningkatkan kemampuan kognitif dalam pembelajaran kimia. Beberapa artikel penelitian yang ditemukan menggunakan multimedia interaktif yang bermacam-macam yaitu Macromedia Flash, Adobe Flash CS6, Web Exe, Aplikasi Android, Chemopoly Game, Game Animasi, Virtual Laboratory, Chemo Edutainment, dan Microsoft Excel.

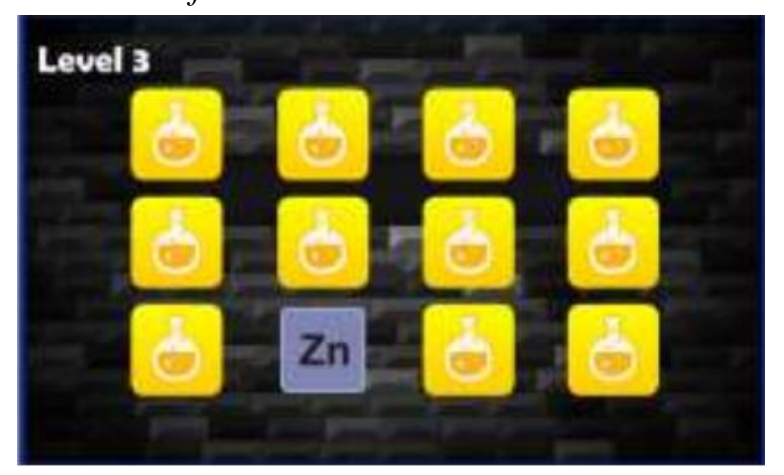

Gambar 1. Contoh Tampilan Menu Game Android
Gambar 1. yaitu gambar contoh sampling fitur multimedia interaktif berbasis android yang dikembangkan oleh Isna Rezkia Lukman dan Andi Maria Ulfa. Hal ini dibuktikan dengan uji coba yang dilakukan oleh Isna Rezkia Lukman dan Andi Maria Ulfa di dalam penelitiannya, bahwa hasil pretest dan posttest peserta didik mengalami peningkatan yang signifikan dari $6,125 \%$ menjadi $87,06 \%$ setelah menggunakan media pembelajaran multimedia interaktif berbasis Android dengan format Android package (.apk) menggunakan software Adobe Flash Professional CS 6 dengan action script 3 ini [46].

Data yang telah diperoleh dari 16 artikel tersebut akan dibuktikan dengan menggunakan uji statistik paired sample. Hasil analisis data dari artikel dipaparkan secara deskriptif kualitatif dan kuantitatif. Persentase hasil pretest dan posttest efektivitas penggunaan media pembelajaran multimedia interaktif dalam pembelajaran kimia dapat diamati pada Tabel 2 .

\section{Tabel 2. Peningkatan Kemampuan Kognitif} Peserta Didik

\begin{tabular}{|c|c|c|c|}
\hline \multirow[t]{2}{*}{ Peneliti } & \multicolumn{3}{|c|}{$\begin{array}{c}\text { Presentase Kenaikan } \\
\text { Kemampuan Kognitif ( } \%)\end{array}$} \\
\hline & Pretest & Posttest & $\begin{array}{c}\text { Pening } \\
\text { katan }\end{array}$ \\
\hline Khaidir (2020) & 42,86 & 75,00 & 32,14 \\
\hline Agung Tri & 34,15 & 75,79 & 41,64 \\
\hline Prasetyo, Sigit & & & \\
\hline Priatmoko, dan & & & \\
\hline Miftakhudin (2008) & & & \\
\hline $\begin{array}{c}\text { Zeynep Tatli dan } \\
\text { Alipasa Ayas } \\
\text { (2013) }\end{array}$ & 39,66 & 59,33 & 19,67 \\
\hline $\begin{array}{c}\text { Ida Hariyanti, } \\
\text { Haryono, dan JS. } \\
\text { Sukardjo (2013) }\end{array}$ & 66,67 & 86,11 & 19,44 \\
\hline $\begin{array}{c}\text { Toto Gusbandono, } \\
\text { JS. Sikardjo, } \\
\text { Suryadi Budi } \\
\text { Utomo (2013) }\end{array}$ & 32,77 & 68,61 & 35,84 \\
\hline Riana Lilis & 43,33 & 56,67 & 13,34 \\
\hline $\begin{array}{l}\text { Widyawati, Suryadi } \\
\text { Budi Utomo, dan } \\
\text { Sulistyo Saputro } \\
\text { (2016) }\end{array}$ & & & \\
\hline
\end{tabular}




\begin{tabular}{|c|c|c|c|}
\hline $\begin{array}{l}\text { Muthmainna Salam, } \\
\text { Muharram, dan }\end{array}$ & 56,66 & 70,00 & 13,34 \\
\hline \multicolumn{4}{|l|}{ Army Aulia (2016) } \\
\hline Gustina, St. & 74,40 & 80,00 & 5,600 \\
\hline \multirow{2}{*}{\multicolumn{4}{|c|}{$\begin{array}{l}\text { Hayatun Nur Abu, } \\
\text { dan Eka Fitriana } \\
\text { Hamsvah (2016) }\end{array}$}} \\
\hline & & & \\
\hline Sri Wahyuni, Amna & 65,60 & 83,60 & 18,00 \\
\hline \multicolumn{4}{|l|}{ Emda, dan Hayatuz } \\
\hline \multicolumn{4}{|l|}{ Zakiyah (2018) } \\
\hline Dian Puspita Eka & 36,80 & 84,69 & 47,89 \\
\hline \multicolumn{4}{|l|}{ Putri,dan Ali } \\
\hline \multicolumn{4}{|l|}{ Muhtadi (2018) } \\
\hline Ratna Kumala & 57,13 & 89,83 & 32,70 \\
\hline \multicolumn{4}{|l|}{$\begin{array}{c}\text { Dewi, Sri Haryani, } \\
\text { dan Sri Wardani } \\
(2018)\end{array}$} \\
\hline $\begin{array}{c}\text { Sarah L. Cresswell, } \\
\text { Wendy A. }\end{array}$ & 65,80 & 87,60 & 21,80 \\
\hline \multicolumn{4}{|l|}{ Loughlin, Mark J. } \\
\hline \multicolumn{4}{|l|}{ Coster, dan David } \\
\hline \multicolumn{4}{|l|}{ M. Green (2019) } \\
\hline Dian Puspita Eka & 36,80 & 84,69 & 47,89 \\
\hline \multicolumn{4}{|l|}{ Putri (2019) } \\
\hline Sihaqqul Firdaus A. & 40,33 & 97,50 & 57,17 \\
\hline H. dan Rusly & & & \\
\hline \multicolumn{4}{|l|}{ Hidayah (2019) } \\
\hline Isna Rezkia & 6,125 & 87,06 & 80,96 \\
\hline \multicolumn{4}{|l|}{ Lukman dan Andi } \\
\hline \multicolumn{4}{|l|}{ Maria Ulfa (2020) } \\
\hline Lenni Khotimah & 79,67 & 87,17 & 7,500 \\
\hline \multicolumn{4}{|l|}{ Harahap dan Anggi } \\
\hline \multicolumn{4}{|l|}{ Desviana Siregar } \\
\hline$(2020)$ & & & \\
\hline Rata-rata & 48,67 & 79,60 & 30,93 \\
\hline
\end{tabular}

Berdasarkan hasil analisis Tabel 2 diketahui peningkatan kemampuan peserta didik dari 16 artikel yang diperoleh menunjukkan persentase rata-rata pretest efektivitas penggunaan multimedia interaktif sebesar $48,67 \%$ dan posttest penggunaan multimedia interaktif sebesar 79,60\%. Hal tersebut menunjukkan terjadinya peningkatan kemampuan kognitif peserta didik sebesar 30,93\%.

Data persentase peningkatan kemampuan kognitif peserta didik dari penggunaan media pembelajaran multimedia interaktif tersebut, kemudian dilakukan analisis uji statistik paired sample dan diperoleh hasil uji statistik yang dapat diamati pada Tabel 3, Tabel 4, dan Tabel 5.
Tabel 3. Paired Samples Statistics

\begin{tabular}{cccccc}
\hline & & & & $\begin{array}{c}\text { Std. } \\
\text { Std. }\end{array}$ & $\begin{array}{c}\text { Error } \\
\text { Mean }\end{array}$ \\
\hline Pair 1 & Pretest & 48.67 & 16 & 19.02809 & 4.75702 \\
& & 22 & & & \\
& Posttest & 79.60 & 16 & 11.24767 & 2.81192 \\
\hline
\end{tabular}

Tabel 4. Paired Samples Correlations

\begin{tabular}{ccccc}
\hline & & N & Correlation & Sig. \\
\hline $\begin{array}{c}\text { Pair } \\
\mathbf{1}\end{array}$ & $\begin{array}{l}\text { Pretest- } \\
\text { Posttest }\end{array}$ & 16 & .172 & .525 \\
\hline
\end{tabular}

Tabel 3 menunjukkan pengujian penggunaan multimedia interaktif pada pembelajaran kimia dari 16 artikel memiliki ratarata kenaikan kemampuan kognitif peserta didik pada pretest sebesar 48,6722 dan mengalami peningkatan menjadi sebesar 79,6031 pada posttest. Sedangkan pada Tabel 4 menunjukkan angka korelasi nilai rata-rata pretest dan posttest mencapai angka korelasi 0,172 . Nilai signifikan pretest dan posttest diperoleh angka $0,525>\alpha$ $(0,05)$ yang berarti tidak ada korelasi antara pretest dan posttest efektivitas penggunaan multimedia interaktif dalam pembelajaran kimia.

Tabel 5. Paired Sample Test

\begin{tabular}{ccccccc}
\hline & & Mean & $\begin{array}{c}\text { Std. } \\
\text { Deviati } \\
\text { on }\end{array}$ & t & Df & $\begin{array}{c}\text { Sig. (2- } \\
\text { tailed) }\end{array}$ \\
\hline Pair & Pretest- & 30.930 & 20.373 & - & 15 & .000 \\
1 & Posttest & 00 & 95 & 6.073 & & \\
& & & & & &
\end{tabular}

Tabel 5 menunjukkan nilai t hitung sebesar -6.073; nilai t hitung digunakan untuk pengujian hipotesis.

Uji hipotesis dapat disimpulkan apabila $\mathrm{H}_{0}$ : tidak terdapat perbedaan yang signifikan terhadap peningkatan kemampuan kognitif peserta didik pada pretest dan posttest efektivitas penggunaan multimedia interaktif dalam pembelajaran kimia. $\mathrm{H}_{1}$ : terdapat perbedaan yang signifikan terhadap peningkatan kemampuan kognitif peserta didik pada pretest dan posttest efektivitas penggunaan multimedia interaktif dalam pembelajaran kimia.

Diketahui:

Th hitung $=-6,073$

$\mathrm{Df} \quad=16$ 
$\mathrm{Dk}$

$$
\begin{aligned}
& =\mathrm{n}-1 \\
& =16-1 \\
& =15
\end{aligned}
$$

Diasumsikan

$\mathrm{T}$ hitung $<\mathrm{T}$ tabel, maka $\mathrm{H}_{0}=$ ditolak dan $\mathrm{H}_{1}=$ diterima

Ditanya:

Maka:

T tabel $=1-1 / 2 \alpha$

$$
\begin{aligned}
& =1-1 / 2(0,05) \\
& =1-0,025=0,975
\end{aligned}
$$

Setelah itu dicari nilai $\mathrm{T}$ tabel dengan $\mathrm{t}$ 0,975 dan $\mathrm{dk}$ 15. Diperoleh nilai $\mathrm{T}$ tabel sebesar 2,131 . Hasil $\mathrm{T}$ hitung $(-6,073)<\mathrm{T}$ tabel $(2,131)$, sehingga $\mathrm{H}_{0}$ ditolak dan $\mathrm{H}_{1}$ diterima maka terdapat perbedaan yang signifikan terhadap kemampuan kognitif yang diperoleh peserta didik pada pretest dan postest efektivitas penggunaan media pembelajaran multimedia interaktif dalam pembelajaran kimia.

Tabel 5 menyajikan uji statistik penggunaan multimedia interaktif terhadap kemampuan kognitif peserta didik dari 16 artikel dengan rata-rata peningkatan 30,09000 dan didapatkan standart deviasi sebesar 20,37395 sehingga dapat diketahui efektivitas penggunaan multimedia interaktif untuk meningkatkan kemampuan kognitif peserta didik menggunakan effect size.

Effect Size $=\frac{\text { Posttest average score-Pretest average score }}{\text { standart deviation }}$

Effect size $=\frac{30,09000}{20,37395}=1,47689$

Berdasarkan hasil olah data effect size maka didapatkan effect size sebesar 1,47689 > 1,0 sehingga penggunaan multimedia interaktif memiliki efektivitas pengaruh yang kuat terhadap peningkatan kemampuan kognitif peserta didik dalam pembelajaran kimia.

\section{SIMPULAN}

Berdasarkan hasil kajian dari 16 artikel diketahui penggunaan multimedia interaktif dalam pembelajaran kimia dapat menjadi pertimbangan sebagai media pembelajaran peserta didik yang dapat meningkatkan kemampuan kognitif peserta didik. Kemampuan kognitif peserta didik menunjukkan peningkatan signifikan sebesar 30,93\%. Hasil ini menunjukkan bahwa multimedia interaktif efektif dapat meningkatkan kemampuan kognitif peserta didik dalam pembelajaran kimia.

\section{DAFTAR PUSTAKA}

1. Suprayekti. 2004. Interaksi Belajar Mengajar Edisi ke-2. Mataram: LPMP Nusa Tenggara Barat.

2. Harahap, L.K., \& Siregar, A.D. 2020. Pengembangan Media Pembelajaran Interaktif Berbasis Adobe Flash CS6 untuk Meningkatkan Motivasi dan Hasil Belajar pada Materi Kesetimbangan Kimia. Jurnal Penelitian Pendidikan Sains, Vol 10, No 1, pp. 1910-1924.

3. Irwanto. 2017. Penggunaan Smartphone dalam Pembelajaran Kimia SMA. Journal for Islamic Social Sciences, Vol 2, No. 1, pp. 81-87.

4. Lightbody, G., McCullagh, P., \& Weeks, C. 2006. The Supporting Role of Emerging Multimedia Technologies in Higher Education. $7^{\text {th }}$ Annual Conference, pp. 46-54.

5. Aldalalah., Osamah, M., Fong, S.F., Ababneh, \& Ziad, W.. 2010. Effects of Multimediabased Instrucyional Designs for Arabic Language Learning among Pupils of Different Achievement Levels. International Journal of Human and Social Science, pp. 311-317.

6. Voogt, J. 2008. Satisfying Pedagogical Practices Using ICT. In: Pedagogy and ICT use in schools around the world, Vol. 1, No. 2, pp. 221-250.

7. Voogt, J., \& Pelgrum, H. 2005. ICT and curriculum change. Interdisciplinary Journal on Humans in ICT Environments, Vol. 1, No. 2, pp. 157175.

8. Wijaya, I K.W.B., Kirna, I M., \& Suardana, I N. 2012. Model Demonstrasi Interaktif Berbantuan Multimedia dan Hasil belajar IPA Aspek Kimia Siswa SMP. Jurnal Pendidikan dan Pengajaran, Vol. 45, No. 1, pp. 88-98.

9. Johnstone, A.H. 1993. The Development of Chemistry Teaching: A Changing Response to Changing Demand. Journal 
of Chemical Education, Vol. 70, No. 9, pp. 701-705.

10. Khaidir. 2020. Penggunaan Media Pembelajaran Interaktif Berbasis Web Exe dalam Meningkatkan Hasil Belajar Kognitif. Jurnal Sudut Pandang, Vol. 1, No. 1, pp. 24-30.

11. Jumadil., Gonggo, S.T., \& Rahmawati, S. 2017. Peningkatan Hasil Belajar Kimia Menggunakan Multimedia pada Materi Ikatan Kimia Kelas X SMK Negeri Parigi Selatan. Jurnal Akademika Kimia, Vol. 2, No. 1, pp. 39-46.

12. Khaeruman \& Hulyadi. 2016. Developing Interactive Fundamental Chemistry Multimedia in Growing Generic Skill for Teacher Training Students. Jurnal Ilmiah Pendidikan Kimia, Vol. 4, No. 1.

13. Astuti, I.D., \& Mulyatun. 2019. Efektivitas Penggunaan Multimedia Pembelajaran Berbasis Multi Level Representasi (MLR) untuk Meningkatkan Hasil Belajar Peserta Didik pada Materi Sistem Koloid Kelas XI MAN Kendal. Journal of Educational Chemistry, Vol. 1, No. 2, pp. 82-91.

14. Brand, S. 1988. The Media Lab: Inventing the Future at MIT. Penguin Books: New York, NY.

15. Wahyuni, S., \& Anis K. 2008. Meningkatkan Hasil Belajar Kimia dan Peran Aktif Siswa Melalui Model PBI Media $C D$ Interaktif. Jurnal Inovasi Pendidikan Kimia, Vol. 2, No. 1, pp. 199-208.

16. Yustiqvar, M., Hadisaputra, S., \& Gunawan, G. 2019. Analisis Penguasaan Konsep Siswa yang Belajar Kimia Menggunakan Multimedia Interaktif Berbasis Green Chemistry. Jurnal Pijar MIPA, Vol. 14, No. 3, pp. 135-140.

17. Mayer, R.E. 2014. The Cambridge handbook of multimedia learning (2nd ed.). New York, NY: Cambridge University Press.

18. Guan, N., Song, J., \& Li, D. 2018. On the advantages of computer multimediaaided English teaching. Procedia Comput. Science Direct, Vol. 131, pp. 727-732.
19. Alemdag, E. \& Cagiltay, K., 2018. A systematic review of eye tracking research on multimedia learning. Comput. Educ., Vol. 125, pp. 413-428.

20. Abdulrahaman, M.D., Faruk, N., Oleyede, A.A., Surajudeen-Bakinde, N.T., Olawoyin, L.A., Mejabi, O.V., ImamFulani, Y.O., Fahn, A.O., Azeez, A.L. 2020. Multimedia tools in the teaching and learning processes: A systematic review. Elsevier, Vol. 6, No. 11, pp. 1-14.

21. Mohamad, R., \& Chong, T.S. 2011. An adaptive multimedia courseware for the students' different cognitive styles: a pilot study for history subject. Elsevier, Vol. 3, pp. 301-306.

22. Dynneson, T.L., \& Gross, R.E. 1999. Designing effective instruction for secondary social studie. Ed. ke-2, Upper Saddle River. New Jersey: Prentice Hall.

23. Hiebert, J., Wearne, D., \& Taber, S. 1991. Fourth grades gradual construction of decimal fraction during instruction using different physical representations. Elementry school jurnal, Vol. 91, pp. 321-341.

24. Mayer, R.E., \& Gahlini, J.K. 1990. Where is an illustration worth ten thousand words?. Journal of Education Psychology, Vol. 82, pp. 715-726.

25. Taqwima, A.H., Ashadi., \& Utami, B. 2013. Studi Komparasi Pembelajaran Kooperatif Metode Teams Game dan Chem-Cards Game pada Materi Pokok Sistem Koloid Kelas XI Semester Genap SMA Negeri 1 Surakarta Tahun Pelajaran 2012/2013. Jurnal Pendidikan Kimia, Vol. 2, No. 4, pp. 165-173.

26. Sundari, E., Saputro, S., \& Mulyani, S. 2014. Pembelajaran Kimia Unsur dengan Model Teams Games Tournament (TGT) Menggunakan Media Game Kartu dan Media Game Animasi Ditinjau dari Motivasi dan Gaya Belajar Siswa. Jurnal FKIP UNS, pp. 1-9.

27. Sani, Z.M., Sudarmin., \& Nurhayati, S. 2016. Pembelajaran Team Game Tournament Berbantuan Media Number Card untuk 
Meningkatkan Keaktifan Siswa. Jurnal Scientia Indonesia, Vol. 1, No. 1, pp. 5665.

28. Viani, D.S., Bahar, A., \& Elvinawati. 2017. Perbandingan Hasil Belajar Siswa Menggunakan Media Chemopoly Game dan Tournament Question Cards. Jurnal Pendidikan dan Ilmu Kimia, Vol. 1, No. 1, pp. 55-59.

29. Mardhiah, A., \& Akbar, S.A. 2018. Efektivitas Media Pembelajaran Terhadap Hasil Belajar Kimia Siswa SMA Negeri 16 Banda Aceh. Lantanida Journal, Vol. 6, No. 1, pp. 49-58.

30. Rumape, O., Christopel, N., Kilo, J.L., \& Kilo, A.L. 2020. Penerapan Pembelajaran Teams Games Tournament (TGT) Dilengkapi Kartu Nama dari Tata Nama Senyawa Kimia untuk Meningkatkan Hasil Belajar Siswa. Jurnal Pendidikan Kimia Indonesia, Vol. 4, No. 1, pp. 4046.

31. Sari, N.P., Yusrizal., \& Khaldun, I. 2015. Efektifitas Media Interaktif Berbasis Microsoft Excel terhadap Peningkatan Keterampilan Proses Sains pada Konsep Kelarutan dan Hasil Kali Kelarutan. Jurnal Pendidikan Sains Indonesia, Vol. 3, No. 2, pp. 56-65.

32. Osman, K., \& Lee, T.T. 2013. Impact of Interactive Multimedia Module with Pedagogical Agents on Student's Understanding and Motivation Learning of Electrochemistry. International Journal of Science and Mathematics Education.

33. Prasetyo, A.T., Priatmoko, S., \& Miftakhudin. 2008. Pengaruh Penggunaan Media Pembelajaran Berbasis Komputer dengan Pendekatan Chemo-Edutainment Terhadap Hasil Belajar Kimia Siswa. Jurnal Inovasi Pendidikan Kimia, Vol. 2, No. 2, pp. 287-293.

34. Tatli, Z., \& Ayas, A. 2013. Effect of a Virtual Chemistry Laboratory on Students' Achievement. Educational Technology and Society, Vol. 16, No. 1, pp. 159-170.
35. Hariyanti, I., Haryono., \& Sukardjo, J.S. 2013. Penerapan Pembelajaran Model Problem Posing dilengkapi Macromedia Flash untuk Meningkatkan Keterampilan Proses dan Prestasi Belajar Siswa pada Materi Kesetimbangan Kimia Kelas XI IPA SMA Negeri Kebakkramat Tahun Pelajaran 2012/2013. Jurnal Pendidikan Kimia, Vol. 2, No. 3, pp. 85-91.

36. Gusbandono, T., Sukardjo, J.S., \& Utomo, S.B. 2013. Pengaruh Metode Pembelajaran Kooperatif Student Team Achievement Division (STAD) dilengkapi Media Animasi Macromedia Flash dan Plastisin Terhadap Prestasi Belajar Siswa pada Pokok Bahasan Ikatan Kimia Kelas X Semester 1 SMA Negeri 1 Sambungmacan Tahun Pelajaran 2012/2013. Jurnal Pendidikan Kimia, Vol. 2, No. 4, pp. 102-109.

37. Widyawati, R.L., Utomo, S.B., \& Saputro, S. 2016. Penerapan Model Pembelajaran Teams Games Turnaments (TGT) Dilengkapi Flash Chemquiz untuk Meningkatkan Minat dan Prestasi Belajar Materi Hidrokarbon Pada Siswa Kelas X8 SMA Negeri 3 Boyolali Tahun Pelajaran 2015/2016. Jurnal Pendidikan Kimia, Vol. 5, No. 4, pp. 75-82.

38. Salam, M., Muharram., \& Aulia, A. 2016. Pengaruh Media Animasi dalam Model Pembelajaran Think Pair Share Terhadap Hasil Belajar Siswa Kelas X Sains SMAN 1 Pinrang Studi pada Materi Pokok Ikatan Kimia. Jurnal Chemica, Vol. 17, No. 2, pp. 103-112.

39. Gustina., Abu, St.H.N., \& Hamsyah, E.F. 2016. Pengaruh Penggunaan Media Pembelajaran Berbasis Macromedia Flash Terhadap Motivasi dan Hasil Belajar Kognititf Siswa Kelas VII SMPN 18 Makassar Studi pada Materi Pokok Asam, Basa, dan Garam. Jurnal Chemica, Vol. 17, No. 2, pp. 12-18.

40. Wahyuni, S., Emda, A., \& Zakiyah, H. 2018. Pengaruh Penggunaan Media Animasi pada Materi Larutan Elektrolit dan Nonelektrolit Terhadap Kemampuan 
Berfikir Kritis Siswa SMA. Jurnal IPA dan Pembelajaran IPA, Vol. 2, No. 1, pp. 21-28.

41. Putri, D.P.E., \& Muhtadi, A. 2018. Pengembangan Multimedia Pembelajaran Interaktif Kimia Berbasis Android Menggunakan Prinsip Mayer pada Materi Laju Reaksi. Jurnal Inovasi Teknologi Pendidikan, Vol. 5, No. 1, pp. 38-47.

42. Dewi, R.K., Haryani, S., \& Wardani, S. 2018. The Influence of Guided Inquiry Learning Assisted Flash Application on Electrolyte Solution Materials Against The Results of Students. Unnes Science Education Journal, Vol. 7, No. 2, pp. 221-228.

43. Cresswell, S.L., Loughlin, W.A., Coster, M.J., \& Green, D.M 2019. Development and Production of Interactive Videos for Teaching Chemical Techniques during Laboratory Sessions. Journal of Chemical Education, Vol. 96, pp. 10331036.

44. Putri, D.P.E. 2019. Penggunaan Media Pembelajaran Berbasis Android untuk Meningkatkan Hasil Belajar Kognitif Siswa. Jurnal Kependidikan dan Sosial Keagamaan, Vol. 5, No. 2, pp. 105-111.

45. H, Sihaqqul F.A., \& Hidayah, R. 2019. The Effect of Using Atomic Models Interactive Multimedia Flash Based on Students Learning Outcames. Atlantis Press SARL, Vol. 1, pp. 198-201.

46. Lukman, R.I., \& Ulfa, A.M. 2020. Meningkatkan Kemampuan Kognitif Kimia Siswa SMA Melalui Pengembangan Media Pembalajaran Berbasis Android. Jurnal Inovasi Teknologi Pembelajaran, Vol. 7, No. 2, pp. 157-164.

47. Saselah, Y.R., M, Muhammad A., \& Qadar, I. 2017. Pengembangan Multimedia Interaktif Berbasis Adobe Flash CS6 Professional pada Pembelajaran Kesetimbangan Kimia. Jurnal Kimia dan Pendidikan Kimia, Vol. 2, No. 2, pp. 8089.
48. Barzegar, N., Farjad, S., \& Hosseini, N. 2012. The effect of teaching model based on multimedia and network on the student learning (case study: Guidance schools in Iran). Social and Behavioral Science, Vol. 47, pp. 1263-1267.

49. Priyambodo, E.. \& Sulistyani. 2014. The Effect of Multimedia Based Learning (MBL) in Chemistry Teaching Learning on Students'Self-Regulated Learning (SRL). Journal of Education and Learning, Vol. 8, No. 4, pp. 363-367.

50. Gunawan., Harjono, A., \& Imran. 2016. Pengaruh Multimedia Interaktif dan Gaya Belajar Terhadap Penguasaan Konsep Kalor Siswa. Jurnal Pendidikan Fisika dan Teknologi, Vol. 12, No. 2, pp. 119-125.

51. Nazir, M.I.J., Rizvi, A.H., \& Pujeri, R.V. 2012. Skill Development in Multimedia Based Learning Environment in Higher Education : An Operational Model. International Journal of Information and Communication Technology Research, Vol. 2, No. 11, pp. 820-828.

52. Supardi, A. 2014. Penggunaan Multimedia Interaktif sebagai Bahan Ajar Suplemen dalam Peningkatan Minat Belajar. Jurnal Ilmiah Pendidikan Dasar, Vol. 1, No. 2, pp. 161-167.

53. Arsyad, A. 2013. Media Pembelajaran. Jakarta: Rajagrafindo Persada.

54. Ansor, S. 2017. Studi Meta Analisis Strategi dan Pemanfaatan Jurnal Elektronik (ejournals) untuk Mahasiswa Lulusan Universitas Negeri Malang dalam Upaya Publikasi Ilmiah Bereputasi Internasional. Record and Library Journal, Vol. 3, No. 1, pp. 63-73.

55. Glass, G.V., B, McGaw., \& Smith, M.L. 1981. Meta-Analysis in Social Research. Sage Publications. London: Sage Publications.

56. Ningsih, S.W., Adi, M.S., \& Saraswati, L.D . 2019. Systematic Review Metode Intervensi Pengetahuan Masyarakat dalam Pengendalian Kasus Leptospirosis di Wilayah Kota Semarang. Jurnal 
Kesehatan Masyarakat, Vol. 7, No. 1, pp. 211-221.

57. C, Francis., \& Baldesari. 2006. Systematic Reviews of Qualitative Literature. Oxford: UK Cochrane Centre.

58. Siswanto. 2020. Systematic Review sebagai Metode Penelitian Mensintesis HasilHasil Penelitian (Sebuah Pengantar). Jurnal Kesehatan Badan Penelitian dan Pengembangan, Vol. 13, No. 4, pp. 326333.
59. Crocetti, E. 2016. Systematic Reviews with Meta-Analysis: Why, When, and How? SAGE Publications, Vol. 4, No. 1, pp. 318.

60. Cooper, H. 2010. Research synthesis and metaanalysis: A step-bystep approach (4th $e d$.$) . Thousand Oaks, CA: Sage.$

61. Sugiyono. 2016. Metode Penelitian Kuantitatif, Kualitatif, dan Kombinasi. Bandung: alfabeta. 